\title{
Hospitalizacja rehabilitacyjna w kryzysie związanym $z$ doświadczaniem szumów usznych jako ramy dla interwencji psychologicznej w procesie adaptacji do dolegliwości
}

\section{Hospital rehabilitation in crisis caused by the tinnitus as framework for psychological intervention in the course of adaptation to distress}

\author{
Małgorzata Fludra, Magda Piełuć, Izabela Sarnicka \\ Instytut Fizjologii i Patologii Słuchu, Światowe Centrum Słuchu, Klinika Rehabilitacji, Warszawa/Kajetany \\ Adres autora: Małgorzata Fludra, Światowe Centrum Słuchu, Klinika Rehabilitacji, ul. Mokra 17, Kajetany, \\ 05-830 Nadarzyn, e-mail: m.fludra@ifps.org.pl
}

\begin{abstract}
Streszczenie
Szumy uszne to percepcja dźwięku będąca wyłącznie rezultatem aktywności systemu nerwowego, bez jakiejkolwiek aktywności mechanicznej w ślimaku. Szumy uszne to problem społeczny - dotyczą około $20,1 \%$ populacji. W pracy przedstawiona została forma pomocy pacjentom z szumami usznymi, jaką są hospitalizacje rehabilitacyjne prowadzone przez psychologów z Kliniki Rehabilitacji Instytutu Fizjologii i Patologii Słuchu (IFPS) w Międzynarodowym Centrum Rehabilitacji (MCR) w Łebie. Celem opisywanych, głównie psychologicznych, oddziaływań opartych na założeniach terapii poznawczo-behawioralnej jest ułatwienie pacjentom adaptacji do dolegliwości, jaką są szumy, a która to dolegliwość, jak pokazują badania, może wywołać kryzys w funkcjonowaniu człowieka - niekorzystnie wpływać na stan psychiczny, styl życia, jakość snu i odpoczynku oraz relacje społeczne. Zadaniem opisywanych hospitalizacji rehabilitacyjnych nie jest leczenie szumów, lecz kształtowanie takich reakcji na szumy w obszarach percepcji, uwagi, emocji i zachowania, które wpłyną na zmianę odczuwania ich dokuczliwości i poprawę funkcjonowania pacjenta w życiu codziennym.
\end{abstract}

W pracy zostały opisane również wstępne wyniki oceniające skuteczność hospitalizacji rehabilitacyjnych w pomocy pacjentom z szumami usznymi.

Słowa kluczowe: szumy uszne • hospitalizacja rehabilitacyjna • adaptacja do choroby

\begin{abstract}
Tinnitus is the perception of sound that results exclusively from the activity within the nervous system without any corresponding, mechanical vibratory activity within the cochlea. Tinnitus is a social problem - it afflict $20.1 \%$ of the population. The aim of this paper is to introduce the psychological assistance to the patients with tinnitus provided by psychologists in the International Center for Rehabilitation in Łeba during the hospital rehabilitations. The object of this mainly psychological assistance, based on assumptions of cognitive behavioral therapy, is to facilitate patients with tinnitus in the course of adaptation to distress caused by the tinnitus. Tinnitus, as researches show, can cause a crisis in patient's life - have negative impact on one's psychical state, life style, impair quality of sleep and rest, as well as the social relations. The described hospital rehabilitation is not aimed at treatment of tinnitus, but shaping specific responses to the tinnitus in the areas of perception, attention, emotions and behavior. It is to generate a change in patient's perception of tinnitus' annoyance level and to bring improvement to the patient's life quality.
\end{abstract}

Also preliminary evaluation of the hospital rehabilitation of the tinnitus patients is included in this paper.

Key words: tinnitus $\bullet$ hospital rehabilitation $\bullet$ adaptation to the distress 


\section{Psychologiczne funkcjonowanie dorosłych pacjentów z szumami usznymi}

Subiektywne szumy uszne są zjawiskiem akustycznym powstającym bez żadnego źródła dźwięku. Są zatem rezultatem aktywności systemu nerwowego bez jakiejkolwiek aktywności mechanicznej w ślimaku. Tylko osoba doświadczająca szumów może określić ich charakter, nasilenie, częstotliwość występowania i stopień dokuczliwości. Nie istnieje żadna obiektywna metoda, która pozwoliłaby potwierdzić bądź też wykluczyć istnienie szumów u danej osoby [1].

Szumy uszne opisywane są przez pacjentów jako m.in. piski, gwizdy, pukania, szelesty, dudnienia itp. Mogą być odczuwane w jednym uchu, obojgu uszach lub w głowie. Według badań przeprowadzonych przez Instytut Fizjologii i Patologii Słuchu [2] szumy uszne trwające dłużej niż 5 minut odczuwa ponad 20\% dorosłych Polaków. Stałe szumy zgłasza około 5\%. Natomiast po 65 roku życia szumy odczuwa około $30 \%$ badanych w populacji amerykańskiej [3].

Doświadczenie z pracy klinicznej z pacjentami z szumami usznymi oraz prowadzone na świecie badania pokazują, że tinnitus może wywierać niekorzystny wpływ na jakość życia pacjentów. Badania Tylera i Bakera [4] wykazały, że u 69,4\% badanych z szumami usznymi pojawiły się problemy emocjonalne, tj.: obniżony nastrój, drażliwość, nerwowość, niepokój, frustracja, napięcie, złość, poczucie beznadziejności. Problemy ze snem miało 56,9\% osób badanych, a 33\% odczuwało pogorszenie zdolności koncentracji.

W badaniu Anderssona i Ericssona [5] pacjenci z szumami potrzebowali więcej czasu na rozwiązanie zadań związanych z selekcją bodźców istotnych i nieistotnych. W badaniu tym kontrolowano ogólny poziom intelektualny pacjentów oraz ich stan emocjonalny. Również w badaniu Rossister i Stevens [6] czas reakcji i uwaga u pacjentów $\mathrm{z}$ szumami były istotnie gorsze niż w grupie kontrolnej.

Rezultaty badania przeprowadzonego przez Kotyło, Merecz, Niebudek-Bugosz i Śliwińską-Kowalską [7] z użyciem kwestionariusza GHQ-28 wykazały występowanie istotnych problemów psychologicznych u pacjentów $\mathrm{z}$ szumami usznymi. Kwestionariusz GHQ-28 umożliwia ocenę problemów pacjenta w czterech obszarach: symptomy psychosomatyczne (GHQ-A), objawy niepokoju i bezsenności (GHQ-B), zakłócenia w codziennym funkcjonowaniu (GHQ-C) oraz symptomy depresji (GHQ-D) [8]. Najczęściej występującym problemem u osób przebadanych przez wymienionych autorów było poczucie bycia chorym - uskarżało się na nie $68 \%$ badanych (skala GHQ-A). Trudności z zasypianiem zgłaszało również $68 \%$ osób, natomiast rozdrażnienie i złość odczuwało $65 \%$ pacjentów (skala GHQ-B), a 36\% zgłaszało problemy w codziennym funkcjonowaniu z powodu szumów (skala GHQ-C).

Problemem często zgłaszanym przez pacjentów z szumami w czasie konsultacji psychologicznych są również trudności z odpoczynkiem. Pacjenci ci nie potrafią wykorzystać czasu wolnego na relaks i odpoczynek z powodu pobudzenia i rozdrażnienia związanego $\mathrm{z}$ nasilonym odczuwaniem szumów w tych sytuacjach. Cisza i spokój intensyfikują bowiem odczuwanie szumów usznych.
Charakter dolegliwości, trudności z wyobrażeniem jej sobie przez osoby niemające szumów albo nieposiadające wiedzy o szumach powodują, że pacjenci często zgłaszają poczucie niezrozumienia przez innych. Pojawienie się szumów wyzwala też, jak pokazały badania Stouffera i Tylera [9], obawę, że jest on objawem poważnej, zagrażającej życiu choroby. Spośród ankietowanych 528 pacjentów, $60 \%$ na początku doświadczania szumów usznych odczuwało taki lęk, natomiast $55 \%$ obawiało się, że z powodu szumów straci słuch.

\section{Szumy uszne jako źródło kryzysu}

Powyższe badania pokazują, że pojawienie się szumów może istotnie wpływać na poznawcze i emocjonalne funkcjonowanie pacjenta i dlatego może stanowić dla niego źródło kryzysu. Jednak pojawienie się szumów nie dla każdego będzie kryzysem i nie każdy będzie miał problemy $z$ adaptacją do życia $\mathrm{z}$ tą dolegliwością. Zgodne jest to $\mathrm{z}$ definicjami kryzysu, które podkreślają ważność subiektywności oceny wydarzenia przez dotkniętego nim człowieka. I tak James i Gilliland [10] przyjmują, że „kryzys jest pewnym sposobem spostrzegania jakiegoś zdarzenia lub sytuacji jako niemożliwej do wytrzymania trudności, która przekracza zasoby i mechanizmy radzenia sobie”. Właśnie rolę tej subiektywnej oceny wydarzenia, jakim są szumy uszne, pokazują wyniki badań Henrego i Wilsona [11]. Używając kwestionariusza Tinnitus Reaction Questionnaire, skorelowali oni odpowiedzi badanych pacjentów $\mathrm{z}$ audiometrycznymi parametrami ich szumów. Wyniki pokazały, że nie istnieje korelacja między głośnością słyszanego dźwięku a jego dokuczliwością. Jednak bardzo głośne szumy zwykle korelowały istotnie z dużą dokuczliwością, a średnia i niska głośność szumów była w bardzo różny sposób odbierana przez osoby badane, jeśli chodzi o dokuczliwość. Te wyniki podkreślają istotną rolę, jaką w postrzeganiu szumów pełnią właściwości psychologiczne, m.in.: pesymizm, zewnętrzne poczucie kontroli, mała elastyczność, negatywne, dysfunkcjonalne przekonania i myśli automatyczne [12].

Tak więc pacjentów $\mathrm{z}$ tinnitusem można podzielić na dwie grupy. Pierwszą stanowią pacjenci, którzy nie doświadczają stresu ani poczucia upośledzenia związanego $\mathrm{z}$ tinnitusem, a tym samym kryzysu psychicznego związanego $\mathrm{z}$ ta dolegliwością. Oni też rzadko skarżą się na szumy i cierpią $\mathrm{z}$ ich powodu. Są to osoby, które albo w ogóle nie zgłaszają się do lekarza z powodu szumów, albo główną przyczyną zgłoszenia się jest chęć wyjaśnienia przyczyny szumów, a nie potrzeba pomocy w radzeniu sobie z szumami w życiu codziennym. Drugą grupę stanowią natomiast pacjenci doświadczający stresu, trudności w codziennym funkcjonowaniu i problemów $\mathrm{z}$ adaptacją do życia z szumami. Pacjenci ci odczuwają lęki, pogorszenie nastroju, złość itp. Szumy utrudniają im koncentrację, często mają problemy ze snem. Szumy zakłócają im odpoczynek, utrudniają aktywność społeczną oraz zawodową. Pojawienie się szumów jest postrzegane jako utrata - utrata ciszy - pacjenci przeżywają żal po stracie, przechodzą przez stadia typowe dla żałoby, w tym depresję [13].

Opisane powyżej, tak różne reakcje pacjentów na szumy uszne potwierdzają, że pojawienie się kryzysu związanego $\mathrm{z}$ wystąpieniem tej dolegliwości jest wynikiem specyficznego połączenia wystąpienia szumów i indywidualnej 
reakcji na to wydarzenie konkretnej osoby. Powyżej omówione badania oraz nasze doświadczenia $\mathrm{z}$ pracy $\mathrm{z}$ pacjentami z szumami usznymi pokazują, że tinnitus jest dla części pacjentów wydarzeniem kryzysowym, przekraczającym możliwości radzenia sobie. Biorąc jednak pod uwagę społeczne występowanie tej dolegliwości oraz jej przewlekły charakter, ważne jest, aby pacjentom mającym trudności $\mathrm{z}$ poradzeniem sobie $\mathrm{w}$ tej sytuacji dać szansę na powrót do wcześniejszego samopoczucia i aktywności.

\section{Hospitalizacja rehabilitacyjna - cel, organizacja oraz rola interwencji psychologicznej}

W Instytucie Fizjologii i Patologii Słuchu formą rehabilitacji, obejmującą interwencje psychologiczne stosowane wobec pacjentów z szumami usznymi, są hospitalizacje rehabilitacyjne prowadzone przez psychologów w Międzynarodowym Centrum Rehabilitacji w Łebie. Hospitalizacja rehabilitacyjna jako forma pomocy pacjentom jest stosowana w Instytucie od 2004 roku. Do tej pory objęto nią blisko dwa tysiące pacjentów. Kwalifikacja na hospitalizacje odbywa się podczas konsultacji audiologicznej i psychologicznej. Pacjenci kwalifikowani do takiej formy rehabilitacji muszą być zdiagnozowani audiologicznie w celu wykluczenia zmian organicznych wymagających interwencji chirurgicznej. Hospitalizacje te są elementem uzupełniającym i rozszerzającym podstawową metodę terapii szumów usznych TRT (ang. Tinnitus Retraining Therapy), która jest leczeniem ukierunkowanym na habituację szumów usznych, wykorzystującym fizjologiczne reakcje zachodzące w mózgu [14].

Ogólnym celem hospitalizacji rehabilitacyjnej jest pomoc pacjentom $\mathrm{w}$ zaadaptowaniu się do życia $\mathrm{z}$ szumami poprzez: zrozumienie dolegliwości, jaką są szumy uszne, akceptację życia $\mathrm{z}$ dysfunkcją, wytworzenie motywacji do różnych aktywności oraz rozwój kontaktów społecznych pomimo istnienia szumów. Interwencje psychologiczne prowadzone w czasie tych hospitalizacji nie mają na celu leczenia szumów, lecz wykształcenie indywidualnych, korzystnych dla pacjenta sposobów reagowania na szumy w sferze postrzegania, uwagi i procesów emocjonalnych, czyli zmianę sposobu reakcji na szumy. Omawiana forma rehabilitacji psychologicznej zakłada aktywny udział pacjenta $\mathrm{w}$ procesie leczenia i rehabilitacji.

Hospitalizacje rehabilitacyjne organizowane przez IFPS trwają tydzień. Pacjenci mają możliwość uczestnictwa $\mathrm{w}$ dwóch takich hospitalizacjach. Odstęp czasowy między kolejnymi pobytami wynosi około roku. Druga hospitalizacja jest kontynuacja terapii prowadzonej w czasie pierwszego pobytu w MCR w Łebie.

Program pobytu opiera się na obowiązujących w świecie teoriach dotyczących leczenia szumów usznych, bazujących głównie na założeniach terapii poznawczo-behawioralnej [12,15]. Duża część prowadzonych ćwiczeń jest autorskim pomysłem, efektem pracy i doświadczenia zespołu psychologów IFPS. Na program hospitalizacji składają się następujące elementy:

1) informacja i edukacja na temat szumów,

2) interwencje psychologiczne, których celem jest zmiana poznawcza dotycząca spostrzegania dolegliwości (obejmują także ćwiczenia kontroli uwagi oraz techniki relaksacyjne i wyobrażeniowe).

\section{Informacja i edukacja na temat szumów usznych}

Pierwszym elementem programu hospitalizacji rehabilitacyjnej jest zapoznanie uczestników z jej celami oraz umożliwienie podzielenia się swoimi doświadczeniami związanymi z omawianą dolegliwością. Ważnym elementem tej części programu jest edukacja dotycząca tinnitusa. Poruszane aspekty dotyczą m.in. częstotliwości występowania szumów, ich lokalizacji, rodzajów dźwięków słyszanych przez pacjentów, możliwości współwystępowania szumów i niedosłuchu, przyczyn pojawienia się dolegliwości oraz leczenia. Niezmiernie ważne jest, aby pacjenci zauważyli i zrozumieli wpływ czynników zewnętrznych (m.in. stresu, zmęczenia, ciszy, hałasu) na subiektywne odczuwanie dokuczliwości szumów. Część edukacyjna ma na celu zmniejszenie lęku związanego z odczuwaniem szumów usznych, lęku przed nieznanym. Otrzymane informacje mogą stać się podstawą do budowy nowej, własnej koncepcji odczuwanej dolegliwości.

\section{Interwencje psychologiczne}

Celem prowadzonych interwencji psychologicznych jest zmiana sposobu spostrzegania, a w konsekwencji doświadczania szumów. Ten etap hospitalizacji to pomoc pacjentom w nauce identyfikacji negatywnych myśli i przekonań, pokazanie powiązań myśli $z$ emocjami i zachowaniami oraz odniesienie tej wiedzy do problemu szumów. „Szum jest coraz głośniejszy”, „Przez te szumy zwariuję i stracę słuch”, „To na pewno coś poważnego” - to przykłady negatywnych myśli i przekonań, które pojawiają się u pacjentów odczuwających tinnitus. Ten etap hospitalizacji wiąże się z przedstawieniem pacjentom podstawowych założeń terapii poznawczo-behawioralnej oraz z przeprowadzaniem eksperymentów behawioralnych. Pokonywanie toru przeszkód z zawiązanymi oczami może być przykładem takiego eksperymentu, który pozwoli pacjentowi doświadczyć sytuacji, w której nie ma on świadomości odczuwania szumów. Dzięki doświadczeniom zdobytym podczas hospitalizacji rehabilitacyjnych pacjenci nabywają umiejętności kontroli negatywnych myśli związanych z szumami oraz identyfikacji i radzenia sobie $\mathrm{z}$ dysfunkcjonalnymi przekonaniami.

Szumy uszne nabierają charakteru choroby wtedy, gdy ich spostrzeganie zajmuje główne miejsce w świadomości pacjenta, tak że inne procesy spostrzegania są ograniczone lub niemożliwe. Dlatego kolejnym ważnym elementem terapii szumów usznych są ćwiczenia kontroli uwagi, które mają na celu odwrócenie uwagi od szumów przez skupianie się na innych bodźcach zewnętrznych czy wewnętrznych. Pacjenci wykonują ćwiczenia zwiększające percepcję sensoryczną, uczą się, że mają wpływ na swoją uwagę, a przez to na mniejsze odczuwanie dokuczliwości szumów usznych. Pacjenci nabywają umiejętności, które dają im poczucie kontroli nad szumami, dzięki czemu zmniejszają stres związany $\mathrm{z}$ ich odczuwaniem.

Wiele osób doświadczających szumów usznych zauważa ich powiązanie ze stresem. Szumy uszne mogą być przyczyną odczuwanego stresu, ale też stres może nasilać odczuwanie szumów. $Z$ uwagi na ten, niezbadany jeszcze do końca, związek stresu z szumami w czasie hospitalizacji rehabilitacyjnych prowadzone są zajęcia relaksacyjne 
i sportowe, proponowane jako sposoby radzenia sobie ze stresem w życiu codziennym. Organizowane są również zajęcia pokazujące mechanizm powstawania stresu, jego przyczyny, wpływ na organizm. Pacjenci uczą się, jak można „zarządzać” stresem w życiu codziennym.

Ze względu na fakt, że hospitalizacje rehabilitacyjne są, jak już wcześniej zostało to zaznaczone, formą wspierającą TRT, dlatego też w czasie ich trwania zostają omówione zasady tej terapii oraz jej możliwości i ograniczenia.

Hospitalizacja rehabilitacyjna jest dla pacjenta rodzajem „poligonu doświadczalnego". Zdobywa on wiedzę i ma okazje wypróbować, często inne niż dotychczas stosowane, strategie rozwiązywania problemów. To pacjent decyduje, które z proponowanych technik są dla niego najlepsze i które będzie stosował w przyszłości. Istotne jest, aby pacjent miał poczucie wpływu, ale i odpowiedzialności za siebie i swoje leczenie oraz świadomość, że potrzebny jest czas i systematyczność, aby stosowane techniki stały się łatwiejsze i bardziej automatyczne.

\section{Efektywność hospitalizacji rehabilitacyjnych pacjentów $\mathrm{z}$ szumami usznymi}

W 2004 roku została przeprowadzona wśród pacjentów, którzy brali udział w hospitalizacjach rehabilitacyjnych, anonimowa ankieta dotycząca skuteczności tej formy terapii. W przypadku $71 \%$ ankietowanych pacjentów hospitalizacje rehabilitacyjne okazały się pomocne w zmniejszeniu dokuczliwości odczuwanych szumów. Ankieta ta pokazała, że taka forma terapii jest skutecznym sposobem pomocy pacjentom cierpiącym z powodu szumów, ułatwia im proces adaptacji do dolegliwości [16].
Obecnie w IFPS prowadzone są kolejne, bardziej wnikliwe, badania nad skutecznością hospitalizacji rehabilitacyjnych. Wstępne wyniki pokazują, że hospitalizacje rehabilitacyjne wpływają na poprawę komfortu życia i istotne złagodzenie dolegliwości związanych z szumami, dzięki czemu pacjenci są w stanie wrócić do swoich obowiązków zawodowych i rodzinnych.

\section{Wnioski}

Podsumowując, szumy uszne ze względu na częstość występowania i wpływ na jakość życia dotkniętych nimi osób są istotnym problemem społecznym w Polsce i na świecie. W pracy przedstawiono efektywny sposób radzenia sobie z tą dolegliwością, jakim są hospitalizacje rehabilitacyjne prowadzone w MCR. Ten rodzaj pomocy odwołuje się do różnych form interwencji psychologicznych w ujęciu poznawczo-behawioralnym. Uwzględnia również złożoną konstrukcję człowieka i nierozerwalność procesów fizjologicznych i psychologicznych, jakie stale w nim zachodzą. Udział w programie hospitalizacji rehabilitacyjnych daje pacjentowi możliwość zdobycia wiedzy o szumach usznych, dowiedzenia się nowych rzeczy o sobie i swoich reakcjach, dzięki czemu doświadczenia wyniesione $\mathrm{z}$ hospitalizacji rehabilitacyjnych mogą stać się inspiracją do dalszego rozwoju osobistego czy do przeprowadzenia zmian w dotychczasowym stylu życia. Nowe doświadczenia zbierane podczas hospitalizacji rehabilitacyjnych pozwalają pacjentom spojrzeć na siebie, swoją dolegliwość i swoje funkcjonowanie z perspektywy innej niż dotychczasowa. Hospitalizacje dają więc szansę pacjentom na zmianę sposobu spostrzegania własnej dolegliwości, dzięki czemu ułatwiają adaptację do szumów usznych. Wydaje się więc, że tego rodzaju hospitalizacje powinny być dostępne dla wszystkich pacjentów mających trudności w radzeniu sobie z szumami usznymi.

\section{Piśmiennictwo:}

1. Bartnik G. Najnowsze hipotezy powstawania szumu w uszach oparte na patofizjologii w różnych miejscach drogi słuchowej. Audiofonologia, 1997; 11: 183-93.

2. Fabijańska A. Badania epidemiologiczne szumów usznych i nadwrażliwości słuchowej na świecie i w Polsce. W: Skarżyński H, red. Szumy uszne i nadwrażliwość na dźwięki. Warszawa: Instytut Fizjologii i Patologii Słuchu; 1998, 35-41.

3. Newman CW. Audiologic management of tinnitus: Issues and options. The Hearing Journal, 1999; 52(11): 10-6.

4. Tyler RS, Baker LJ. Difficulties experienced by tinnitus sufferers. J Speech Hear Disord, 1983; 48: 150-4.

5. Andersson G, Ericsson J, Lundh L, Lyttkens L. Tinnitus and cognitive interference: a Stroop Paradigm study. J Speech Lang Hear Res, 2000; 43: 1168-73.

6. Rossiter S, Stevens C, Walker G. Tinnitus and its effect on working memory and attention. J Speech Lang Hear Res, 2006; 49: 150-60.

7. Kotyło P, Merecz D, Niebudek-Bugusz E, Śliwińska-Kowalska M. Program oceny i interwencji psychologicznej u pacjentów z szumami usznymi. Otorynolaryngologia - Przegląd Kliniczny, 2006; 5(4): 189-94.

8. Goldberg D, Williams P. Podręcznik dla użytkowników Kwestionariusza Ogólnego Stanu Zdrowia. Łódź: Instytut Medycyny Pracy im. prof. J. Nofera; 2001.
9. Stouffer JL, Tyler RS. Characterization of tinnitus by tinnitus patients. J Speech Hear Disord, 1990; 55: 439-53.

10. James RK, Gilliland BE. Strategie interwencji kryzysowej. Warszawa: Państwowa Agencja Rozwiązywania Problemów Alkoholowych; 2006.

11. Henry JL, Wilson PH. Coping with tinnitus: Two studies of psychological and audiological characterstics of patients with high and low tinnitus-related distress. Int Tinnitus J, 1995; 1: 85-92.

12. Henry JL, Wilson PH. The psychological management of chronic tinnitus. A Cognitive-Behavioral Approach. Boston: Allyn and Bacon; 2001.

13. Dodziuk A. Żal po stracie, czyli o przeżywaniu żałoby. Warszawa: Instytut Psychologii Zdrowia PTP; 2001.

14. Bartnik G, Fabijańska A, Raj-Koziak D, Borawska B, Karpiesz L. Wyniki habituacji szumów usznych i nadwrażliwości słuchowej metodą Tinnitus Retraining Terapy. Otorynolaryngologia, 2003; 2(2): 83-9.

15. Andersson G. Psychological aspects of tinnitus and the application of cognitive - behavioral therapy. Clin Psychol Rev, 2002; 22(7): 977-90.

16. Borawska B, Bartnik G, Karpiesz L, Szymańska E, Senderski A, Skarżyński H. Wstępna ocena przydatności terapii dźwiękowej u pacjentów z szumami usznymi i/lub nadwrażliwością słuchową leczonych metodą habituacji (TRT). Audiofonologia, 2004; 24: 145-53. 